\title{
オルガノソルブ脱リグニン
}

\author{
九州大学農学部 坂 井 克 已
}

\section{Organosolv delignification}

\author{
Kokki Sakai \\ Faculty of Agriculture, Kyushu University
}

\begin{abstract}
Development of some organosolv pulping systems including phenol, solvolysis and organic acid processes have been reviewed. The Alcell process and the Organocell process are also dealt with. Special emphasis is placed on the production mechanism of eugenol and isoeugenol from lignin during alcohol-bisulfite delignification.
\end{abstract}

\section{1.はじめに}

1930 年代に始まったオルガノソルブパルプ化

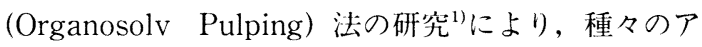
ルコールやフェノールも酸触媒の存在下に脱リグニン 作用を有する事が明らかになった。その後も断続的に DMSO, DMF，トリエチレングリコール等の溶媒が とりあげられ，脱リグニンに有効であると報告されて きた2)。しかし，安価なパルプを製造するのに， $100 \%$ 近く回仪されるとは言え高価な有機溶媒を使う という久点を持つのも事実である。他方，パルプ化に 伴って生じる環境污染が世界的に注目された 1970 年 頃, 無公害型パルプ化法としてオルガノソルブパルプ 化法が見直され，引き続く 2 度のオイルショックは化 石資源の節約とともにパルプ化に伴うエネルギー消費 に目を向けさせることになった。以来, 消エネルギー 的であるのみならず副産物をも含めたバイオマスの総 合利用を指向して，オルガノソルブパルプ化法は継続 的に研究されており，今日ではパイロットプラントや 実機規模の装置が建設されるに至っている。ここでは, フェノール類による脱リグニン, 有機酸パルプ化, ア ルコールを用いるパルプ化などについて概観し，アル コール・サルファイト蒸解におけるリグニンの低分子 化反応についてやや詳しく述べてみたい。なお，常圧 下のソルベントパルプ化については優れた総説 ${ }^{3}$ があ るのでご参照頂きたい。

\section{2. フェノール類による脱リグニン}

約 20 年前に Schweers らが提案したフェノールパ
ルプ化法 ${ }^{4)} の$ 概念は, 少量の酸触媒（例えば $0.5 \% \mathrm{HCl}$ ) を含むフェノール水溶液中 $160 \sim 170^{\circ} \mathrm{C} て ゙$ 木材を処理 するものである。フェノールの沸点が高いため常圧下 で蒸解できること, 溶出リグニンの熱分解生成物を蒸 解溶媒として再利用し得ることなどの特長を持ってい た。しかし，パルプの洗浄にメタノールあるいはイソ プロピルアルコールのような有機溶媒を用いており, フェノールのみならずこれらの溶媒をパルプから分 離・回収する必要があった。また得られたパルプの脱 リグニン度は必ずしも満足できるものではなかった。

彼らの研究はその後, スイスの Battelle Geneva Inst. によるバイオマスフラクショネーションプロセ $ス^{5)}$ あるいは榊原らによって提案されたりルボリシ

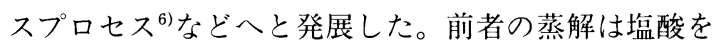
触媒にしてフェノール中 $100^{\circ} \mathrm{C}$ 前後, 常圧で行われ, この点が無触媒ソルボリシス法と異なる。蒸解廃液か らフェノール類を再生すると共に燃料油や糖質を副生 成物として得ることを前提にして，10万 $\mathrm{t} /$ 年のパル プ生産規模の設備が成立すると試算している。得られ たパルプは溶解用パルプに適するといわれる。榊原ら のソルボリシスパルプ化法も基本概念は Schweers ら のフェノール化に類似しているが, 溶媒としてクレゾ 一ルを用いて鉱酸を触媒としない点が異なっており, 結果的に高い蒸解温度 $\left(180 \sim 190^{\circ} \mathrm{C}\right)$ を必要とするが, パルプ収率は高く紙力も優れており，製紙用パルプに 適するデー夕が公表されている。

両プロセスとも図 1 に例示するような物質収支が見 込まれており，廃液中のリグニンからの溶媒（フェ） 一ル類）回収及び高付加価値副産物の生産が重要な鍵 


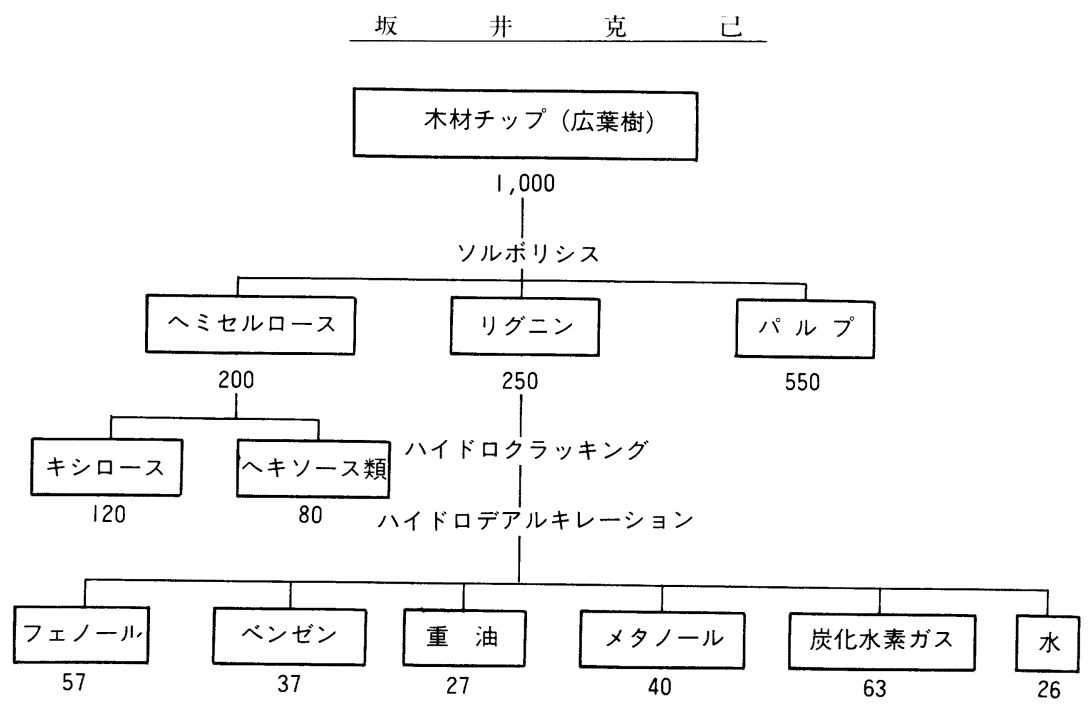

Fig.1 ソルボリシスパルプ化物質収支（榊原，1982）

プロセスとなる。これついては Hydrocarbon Res. Inc. からクラフトリグニンを原料として流動床方式 でハイドロクラッキングとハイドロデアルキレーショ ンを行う，いわゆるリグノールプロセスが提案7され たが，用いられる触媒や反応条件等の詳細は未公表の ようである。私見ではあるが, リグニンの大部分を低 分子の高付加価值物質に導いて，これを分別・精製・ 回収することは，もし可能としてもそのための工程及 び水素のような物質とエネルギーを必要とすることに なり得策ではないであろう。また，実際面を考えると 製品パルプや廃水中に残存するフェノール類の除去は 容易でないと思われる。

その後, ソルボリシスプロセスに関しては北大農学 部をはじめ日本紙パルプ研究所などが研究を継続し成 果を挙げている3)。

\section{3. 有機酸パルプ化}

酢酸や蟻酸のような有機酸による脱リグニンも研究 され, Young ら ら $^{8}$ 無触媒で含水酢酸（50 87.5\%） による蒸解 $\left(175^{\circ} \mathrm{C}, 1 \sim 4 \mathrm{~h}\right)$ を行い, $\mathrm{KP}$ と $\mathrm{SP}$ の中 間の強度を持つパルプを得た。さらに, 彼らは酷酸一 水-酢酸エチルの約 $1: 1: 1$ 混液（図 2 の三角形のほ ぼ中央）で蒸解後, 廃液に酢酸エチルを添加すると, 溶媒組成は図 2 の相分離領域に移動して溶媒回収が容 易になることを根拠に, エステルパルプ化を提唱し た ${ }^{8 b)}$ 。しかし, 酢酸エチルは水にかなり溶ける $\left(25^{\circ} \mathrm{C}\right.$ で約 10\%）ので損失の大きいことが懸念される。

鉱酸触媒を添加すると酢酸の沸点近傍の常圧脱リグ ニンを行えることから, 塩酸 $\left(\mathrm{Nimz} ら^{9)}\right)$, 硫酸 (佐

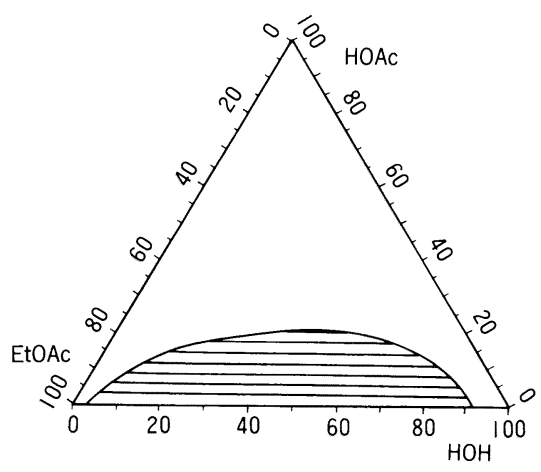

Fig.2 酢酸一酢酸エチルー水系の相図 ${ }^{8 \mathrm{~b})}$ 三部分は 2 相分離を示寸

野ら ${ }^{3,10)}$ 添加による常圧酢酸パルプ化が研究され, 木材成分総合利用研究技術組合でも取り上げられた ${ }^{11}$ 。 その結果, 高濃度（例えば 90～95\%）の酢酸中で少 量（2\%以下）の鉱酸を用いて数時間惹沸することに より脱リグニンの進んだパルプが得られる。100 t/d のパルプ生産規模を想定したプラントのフロー略図も 示されている ${ }^{11)}$ 。溶出したリグニンは相分離によって 容易に回収されて，炭素繊維 ${ }^{12)}$ や接着剂 ${ }^{13)}$ な゙への応 用が検討されている。

筆者は若い頃りグニンの過酢酸分解を研究したこと があり，フィンランド紙パルプ研究所で開発された蟻 酸と過酸化水素の併用による過蟻酸パルプ化 (MILOX 法）には深い興味を覚える。これについては文献引に 詳しく解説されているのでここでは省略する。 


\section{4. アルコール等を用いるパルプ化}

既述のように約 60 年前から研究の蓄積がある。検 討された多くの溶媒のうち DMSO, グリコール，エ 夕ノールアミンなどのように高沸点で蒸発熱の大きい 溶媒は回収に難点がある。しかし, 低沸点アルコール と水の混液による蒸解はKleinertによる再評価 $(1974 \text { 年 })^{14)}$ 以来, 図 3 に示すように溶媒回収後の廃 液から容易に不溶性リグニンと糖溶液とを分離する方 法として注日され, 経済的に成立するという試算も出 された。その後の追試により無触媒では特に針葉樹の 脱リグニンが困難だとされ, 種々の触媒（水酸化ナト リウム, 硫酸, 塩酸, 酢酸, サリチル酸, 塩化アルミ 二ウム, 硫酸アルミニウム, 硫酸マグネシウム, 塩化 カルシウム, 硫化アンモニウム等) が提案された。

アルカリを助戍とするメタノール蒸解については 1976〜1978 年にかけて中野らの先駆的研究に引き続 いて日本紙パルプ研究所でも詳細に検討された ${ }^{19)}$ 。 $\mathrm{KP}$ に勝るとも劣らないパルプ品質と収量が得られた

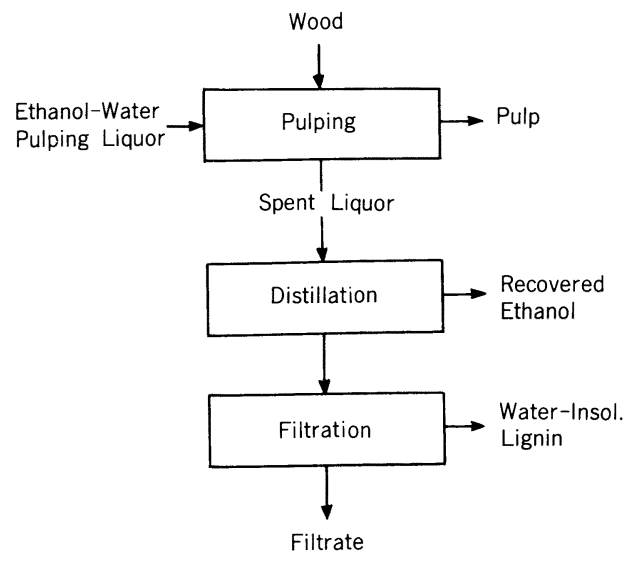

(Hemicellulose Sugars, Soluble Oligolignols)

Fig.3 オルガノソルブパルプ化の概念困 (Sarkanen, 1985)
が, 経済性評価の結果, メ夕ノールの回収のためクラ フトパルプより割高で近い将来経済的に成立する可能 性は少ないと予想された ${ }^{20)}$ 。や遅れてドイッでは, 第 1 段に無触媒メタノール（約 $50 \%$ ）中で $195^{\circ} \mathrm{C}$ 以下 に加熱後，第 2 段にアルカリとアントラキノンを添加 して蒸解 $\left(165^{\circ} \mathrm{C}\right)$ する Organocell プロセスが開発 された（表 1 , 表 2, 図 4, 図 5 参照)。 $5 \mathrm{t} / \mathrm{d}$ 規模の 実証プラント試験 ${ }^{21)}$ の成果に基づいて，1992 年完工 を目指してドナウ河畔の Kelheimに 12 15 万t/年 の工場建設が行われたようである ${ }^{22)}$ 。実操業の結果は 目にしていないが，溶媒の回収と副産物リグニンの利 用が円滑に行われることが必須であろう。ドイツでは また, アルカリ性サルファイト・アントラキノン・メ タノール (ASAM) 法が開発され ${ }^{23)}, 3 \mathrm{t} / \mathrm{d}$ のパイロ ットプラントが 1990 年に設置されている。KP 工場 が許可されないドイツと我が国では事情が異なるにし ても，注目してよい動きであろう。

一方，エ夕ノール・水による無触媒（実際には木材 から遊離した酢酸や蟻酸が触媒作用を持つ）パルプ化 とリグニンおよびへミセルロースの生産とを組み合わ せたAlcohol Pulping and Recovery (APR) プロ セス ${ }^{15)}$ の実現を目指してパイロットプラント実験が行 われな スとして, カナダでは 1989 年 3 月以来, パルプ生産 $15 \mathrm{t} / \mathrm{d}$ 規模の実証プラントが運転され, $5 \mathrm{t} / \mathrm{d}$ (木材 の $18 \%$ ）の Alcell リグニンも生産されている ${ }^{17)}$ 。蒸 解は図 6 に示す抽出管内で向流的に 3 段階に分けて行 われる。すなわち, 新しいチップは先ず, リグニン分 解物や酢酸をある程度含み $\mathrm{pH}$ が約 4 まで低下した排

Table 1 Organocell Processにおける蒸解条件 ${ }^{22)}$

Alcohol/Water/Sodium Hydroxide/AQ

Alcohol concentration : $20 \sim 30 \%$ in liquor

$\mathrm{NaOH}: 19 \sim 22 \%$ on OD wood

Temperature : $155 \sim 160^{\circ} \mathrm{C}$

Time : 60 150 min.

Table 2 パルプの強度試験結果 ${ }^{21)}$

\begin{tabular}{lrrr}
\hline & Organocell & Kraft & Magnefite \\
\hline $\mathrm{NaOH}, \%$ & 20 & 20 & 15 \\
Tensile Strength, m & 7,900 & 8,500 & 6,300 \\
Burst Strength, $\mathrm{kPa}$ & 350 & 470 & 320 \\
Tearing Resistance, $\mathrm{mN} \cdot \mathrm{m} / \mathrm{m}$ & 1,000 & 1,100 & 810 \\
Folding Endurance & 730 & 1,000 & 530 \\
\hline
\end{tabular}




坂井克过

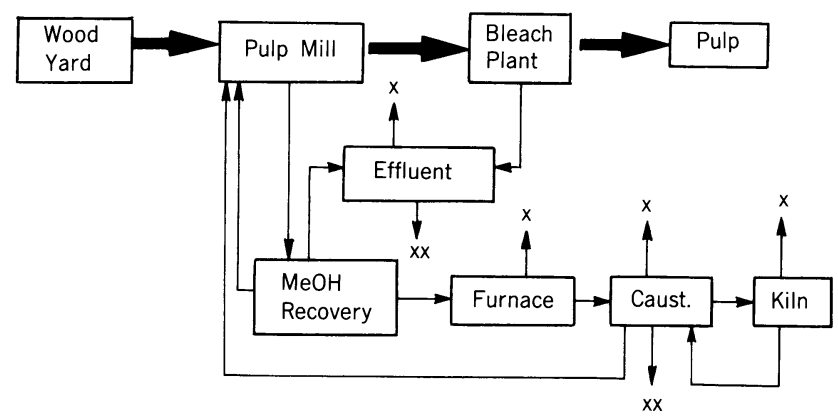

$\mathrm{x}=\mathrm{H}_{2} \mathrm{O}$ (Steam)

$x x=$ Municipal Waste, Landfill, Use in Bricks

Fig.4 Organocell Process のフロー略龱 ${ }^{22)}$

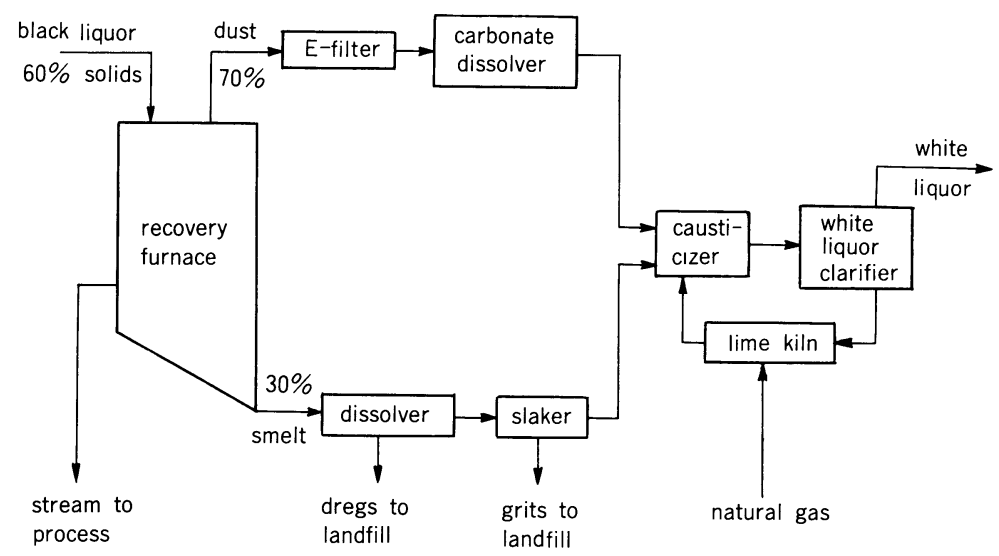

Fig.5 Organocell Process における薬品回収のフロー 22

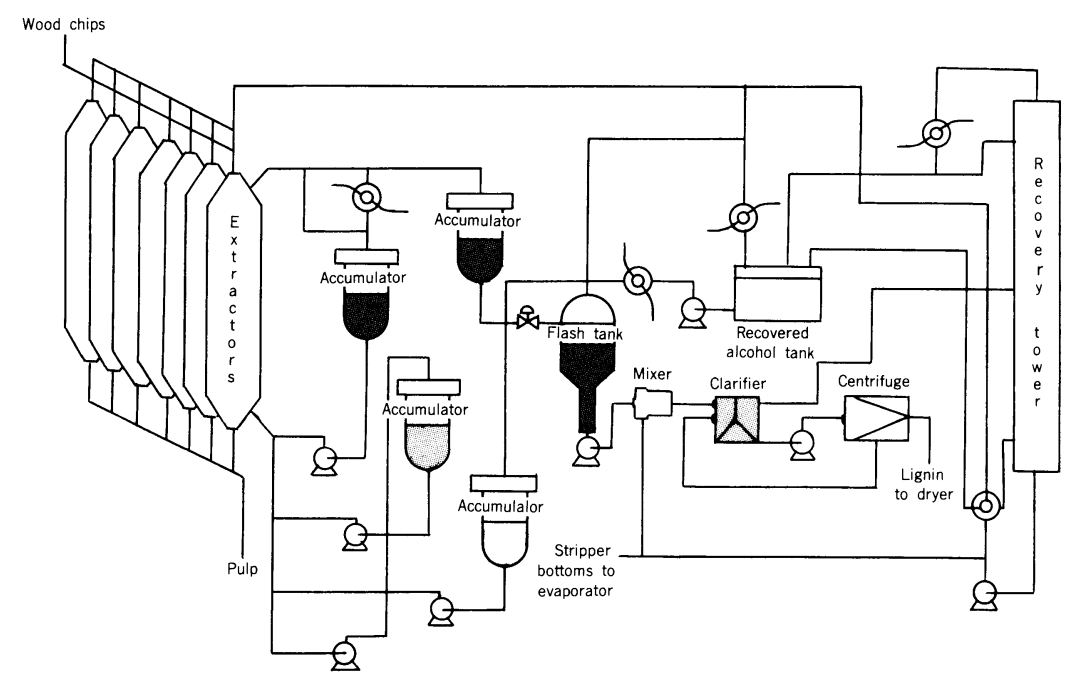

Fig.6 Alcell プロセス ${ }^{17)}$ 
液とともに加熱される。パルプ化の過程で脱リグニン

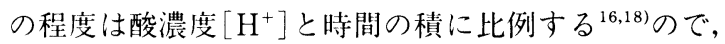
これは合理的な力法である。パルプ化工程は約 50 重 量\%エタノール, 無触媒, $195^{\circ} \mathrm{C}$ (約 $\left.27 \mathrm{~kg} / \mathrm{cm}^{2}\right)$ の 条件で, 抽出液の置換 (パルプ洗浄) を含めて 1 サイ クル 5 時間程度を要する。蒸解廃液をフラッシュして 大部分のアルコールを回収後, リグニンを分離した後 の液相から蒸留によりさらにアルコールとフルフラー ルが得られ，後者は精製後に販売する計画がある。 Alcell プロセスは現在のところ漂白用広葉樹パルプ の製造に用いられ，針葉樹には不適当である。

\section{5. アルコール・サルファイト蒸解における}

\section{低分子フェノールの生成}

アルコール・サルファイト蒸解はいくつかのグルー プ24 26)により独立に提案された方法で, サルファイ 卜系蒸解液にアルコールを加えることから始まった。 我々は当初, 難蒸解性のスギ材を SCP 原料とするに 当りイソプロパノールを添加した結果, 解繊エネルギ 一の大幅な節約と闰時に脱リグニンの促進を観察した。 その後, 対パルプ $6 \%\left(\right.$ as $\left.\mathrm{SO}_{2}\right)$ の $\mathrm{Mg}\left(\mathrm{HSO}_{3}\right)_{2}$ を含

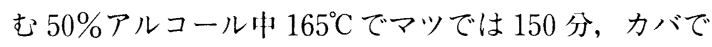
は 90 分前後蒸解することにより, KPより最大 $6 \%$ 高収率で化学パルプが得られた27)。パルプの漂白は非 常に容易であるが, 強度はKPのものと比べてやや 劣る結果であった（表 3 )。このパルプ化法の最も大 きい特徴は，木材のリグニンに対して $3 \sim 5 \%$ （即ち 木材当り約 $1 \%$ 以上）のオイゲノール及びイソオイゲ

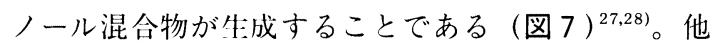
のオルガノソルブパルプ化においても, 䓏解液から分 離・回収したリグニンを原料として, 炭素繊維や接着

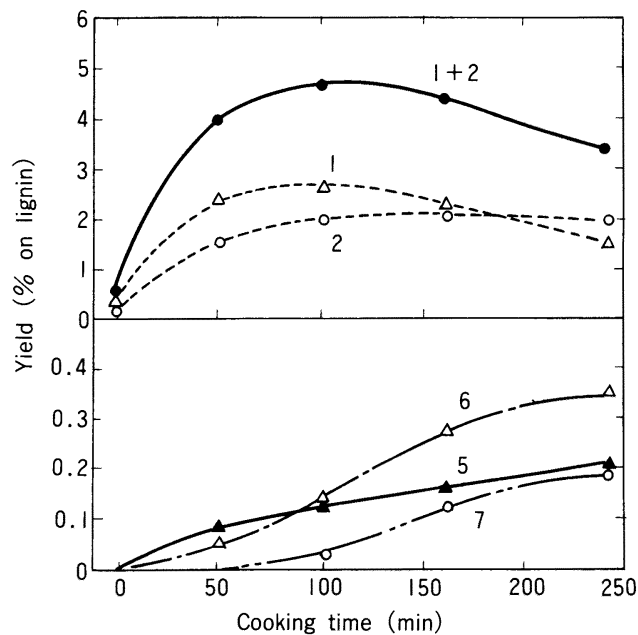

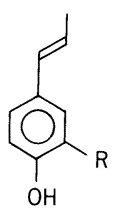

I $\mathrm{R}=\mathrm{OCH}_{3}$

$3 \mathrm{R}=\mathrm{H}$

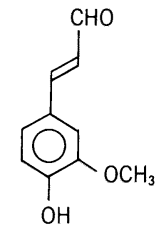

7

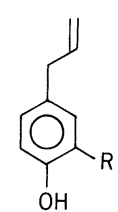

$2 \mathrm{R}=\mathrm{OCH}_{3}$ $4 \mathrm{R}=\mathrm{H}$
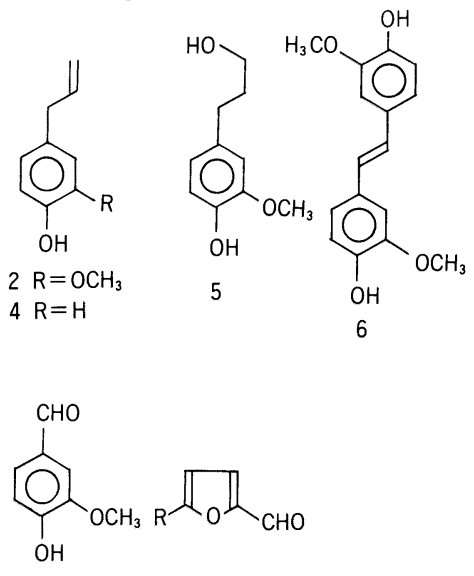

$9 \mathrm{R}=\mathrm{H}$

$10 \mathrm{R}=\mathrm{CH}_{2} \mathrm{OH}$

Fig.7 スギ材のアルコール・サルファイト蒸解で副 生する低分子化合物（1：イソオイゲノール， $2:$ オイゲノール)

Table 3 アルコール・バイサルファイトパルプと $\mathrm{KP}$ の比較（強度は $350 \mathrm{~m} l \mathrm{CSF}$ )

\begin{tabular}{clcccccc}
\hline Type of pulp & $\begin{array}{c}\text { Bleached } \\
\text { pulp yield }(\%)\end{array}$ & $\begin{array}{c}\text { Brightness }^{\mathrm{a})} \\
(\%)\end{array}$ & $\begin{array}{c}\text { Density } \\
\left(\mathrm{g} / \mathrm{cm}^{3}\right)\end{array}$ & $\begin{array}{c}\text { Tear } \\
\text { factor }\end{array}$ & $\begin{array}{c}\text { Burst } \\
\text { factor }\end{array}$ & $\begin{array}{c}\text { Breaking } \\
\text { length }(\mathrm{km})\end{array}$ \\
\hline \multirow{3}{*}{ Pine } & Kraft & 45.2 & 87.6 & 0.750 & 145 & 8.0 & 9.2 \\
\cline { 2 - 7 } & $i s o-\mathrm{PrOH}$ & 47.6 & 88.5 & 0.805 & 109 & 5.8 & 7.4 \\
& sec-BuOH & 48.0 & 89.3 & 0.812 & 126 & 6.0 & 7.8 \\
\hline \multirow{3}{*}{ Birch } & Kraft & 51.2 & 87.5 & 0.873 & 109 & 8.3 & 10.7 \\
\cline { 2 - 7 } & $i s o-\mathrm{PrOH}-1$ & 52.0 & 88.7 & 0.885 & 104 & 6.9 & 9.0 \\
& sec-BuOH-1 & 51.0 & 89.4 & 0.899 & 118 & 7.4 & 9.3 \\
\hline
\end{tabular}

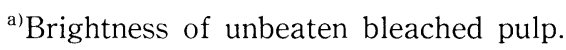

Notes: Blached alcohol-bisulfite pulp were beaten in a PFI mill at a load of $1.0 \mathrm{~kg} / \mathrm{cm}$ and bleached Kraft pulps at $1.8 \mathrm{~kg} / \mathrm{cm}$. 
剤などの調製が研究されている。しかしながら，これ らは新たな製造工程を必要とするのに対し，前記の化 合物はすでに蒸解によって生成している。

一般にパルプ製造時に生成する低分子量のリグニン 分解物の収率は低く，その単離は容易ではない。しか も用途がはっきりしない場合が多い。Sarkanen ら ${ }^{29)}$ は硫化アンモニウム・アルコール蒸解により 2 ○\% のアセトグアイアコン及びプロピオグアイアコンが副 生することを発見したが，その経済的な単離は容易で なく用途も不明である。これに対しアルコール・サル ファイト蒸解時に副生するオイゲノール及びイソオイ ゲノールは溶媒回収時に蒸留により簡単に単離できる。 我が国では香料として両者合計で年間 $200 \mathrm{t}$ 程度輸 入・製造されている。その単価はパルプ価格の数十倍 であり，もし売却できれば単離や溶媒回収のコストを 補って余りある計算になる。但し，オイゲノールもイ ソオイゲノールも, 所謂ファインケミカルスに属し大 量の需要は見込めないことには留意すべきである。

\section{6. アルコール・サルファイト処理による}

\section{$\beta-0-4$ 型結合の開裂反応}

前述のようにアルコール・サルファイト法による針 葉樹のパルプ化のさい, 溶出リグニンの一部は低分子 フェノール類にまで分解される。この低分子フラクシ ヨンの主体はイソオイゲノールとオイゲノールであり, 両者の合計収率はプロトリグニンあたり 3 5\%に達 する。また，広葉樹からはこれらの外に 4-allylsyringol と 4-propenylsyringol が生成する27)。この事実はり グニンの化学反応の立場からも興味深いと考えて, そ の生成機構について研究した ${ }^{30)}$ 。

\section{1) 反応の特徵}

マグネシウムバイサルファイトを含む $50 \%$ イソプ

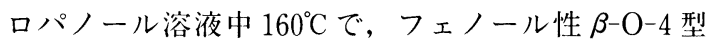
モデル化合物グアイアシルグリセロール $\beta$-グアイア シルエーテル（11）とその類縁化合物（12）を処理し た (図 8 参照)。この処理条件は我々が木材の蒸解の とき普通に用いる条件に近い。化合物（11）から約 50\%収率のグアイアコール (14) の外に, イソオイゲ ノール（1）とオイゲノール（2）が合計約 $40 \%$ の収 率で得られた。同じ条件下で $\alpha$-カルボニル誘導体及 び $\alpha$ メチレン誘導体からは, イソオイゲノールが生 成しないのは勿論, グアイアコールの収率も大変低か つた。 $\alpha$-位のスルホン化は上:述の $\beta-\mathrm{O}-4$ 結合開裂反 応と競争的であった。一方, 非フェノール性 $\beta-O-4$ 型化合物からは同じ処理で痕跡量のグアイアコールが 生じたのみで，オイゲノールもイソオイゲノールも全 く検出されなかった。したがって,アルコール・バイ サルファイト処理時の初発 $\mathrm{pH}$ はかなり低い（約 4.5）けれども, 反応はキノンメチドを経由して進む と考えなければならない。

またコニフェリルアルコール（15）を類似の条件で 処理すると, 合計 $36 \%$ の収率でオイゲノールとイソ オイゲノールが得られた。スギ木粉の場合には一旦コ ニフェリルアルコールが生成し, その量は $160^{\circ} \mathrm{C}$ まで 増加した後, 急速に減少した。これらのことから, コ ニフェリルアルコール（15）は最終生成物オイゲノー ル（1）又はイソオイゲノール（2）に至る中間体であ ることが明らかである。

以上の結果から, 開裂反応は図 8 に示すようにリグ ニン中のフェノール性で非縮合型の $\beta-\mathrm{O}-4$ 型構造か ら, キノンメチドを経由して進行し, 還元開裂生成物

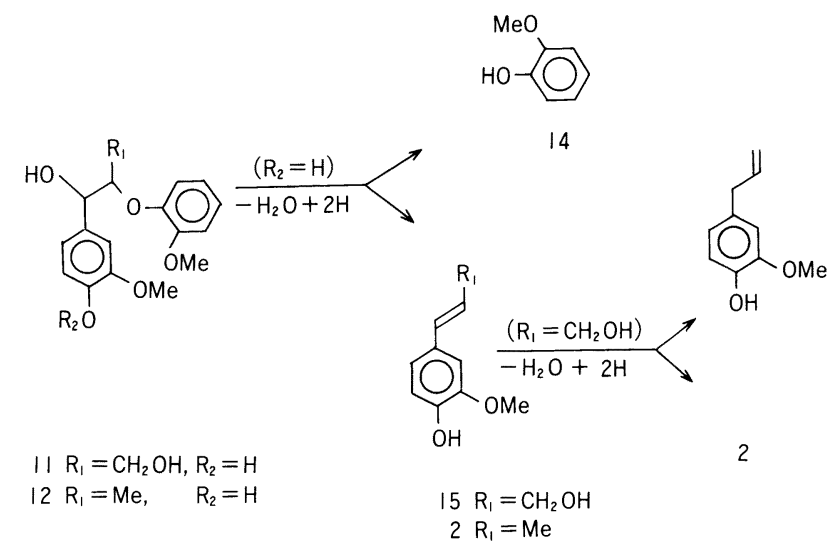

Fig.8 モデル化合物の反応スキーム 
であるコニフェリルアルコール（15）が中間体として 生じ，これが更に還无及び脱水されて 1 及び 2 に変化 するものと考えられる。

ところで，プロトリグニン中には $\mathrm{C}_{6}-\mathrm{C}_{3}$ 単位当り， フェノール性水酸基を持つ単位 (A) は 0.1 個 $^{31)}$ ，非 縮合型（B）は最人 0.5 做 $^{32)}, \beta-\mathrm{O}-4$ 型構造 (C) が $0.4 \sim 0.5$ 㑬 $^{32)}$ 你在すると見積られる。これらの単位 が均一に分布しているとすれば，プロトリグニンから 生じる 1 と 2 の合胡收率 $(\mathrm{Y})$ は：

$$
\mathrm{Y}=50 \times \mathrm{A} \times \mathrm{B} \times \mathrm{C}=1 \sim 1.25 \%
$$

となる（ここで50（\%）は，モデル化合物からの 1 と 2 の合胡仪摔)。具際にはスギ木粉からの収率は約 $5 \%$ あ゙あなから，図 9 に小寸ように $\beta-\mathrm{O}-4$ 結合を持 つ単位が平均 4 5 湖連続して開裂寸るものと思われ る。また， スギ材からの収摔はマツ材からの収率と比

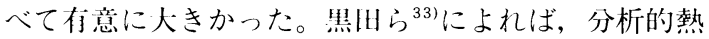
分解に打けるコニフェリルアルコールの収率もスギ材 と比べてマツ材が小さい。これらの事実は針葉樹リグ ニンの側鎖構造の樹種間差に関係していると考えられ る。今後, 側鎖構造を調べる手段としてアルコールバ イサルファイト処理による低分子フェノールの収率測 定を用い得るかもしれない。

\section{2） 反応条件の影響}

リグニンのフェノール性 $\beta-\mathrm{O}-4$ 単位からイソオイ ゲノールとオイゲノールを生成する反忍にはアルコー ルと $\mathrm{HSO}_{3}{ }^{-}$の共你が不叮久である。また, この反応
は既知の加水分解，アルコリシスあるいは sulfitolysis 条件下では起らないことが分かった。

上記のモデル化合物（12）を用いて検討したところ， 種々の溶媒（50\%水溶液）のうちアルコール類及びジ メチルホルムアミドはイソオイゲノール生成に有効で あった。しかし，ジメチルスルホキシドや酢酸などを 用いると $\beta-\mathrm{O}-4$ 結合の開裂反応は起こるもののイソ オイゲノール収率は大変小さかった（図 10）。一方, $\mathrm{pH} 4$ のアルコール・水溶液中に覀硫酸水素イオン $\left(\mathrm{HSO}_{3}{ }^{-}\right)$が無いNon-bisulfite 系では, モデル化合 物は消費されるがイソオイゲノールは殁ど生成しない (図 11)。イソオイゲノールの生成には 1 moleの $\mathrm{HSO}_{3}{ }^{-}$が必要であるが, それ以上添加しても生成量 には殆ど影響しなかった（図 11）。これらのことから， 化合物（12）から生成するキノンメチド中間体のホモ リシスによって生じなグアイアコールラジカルやイソ オイゲノールラジカルが $\mathrm{HSO}_{3}{ }^{-}$によって還元されて 最終生成物にいたるものと考えられる。このさい高濃 度の有機溶媒の存在はむしろ反応を遅らせる（図 11） が, これはキノンメチド生成速度が小さくなるからで あろう。他方，リグニンの縮合反応は有機溶媒によっ て抑制される。したがって，アルコール濃度約 $50 \%$ 付近にイソオイゲノール収率の極大が現れるのは，前 記の開裂反応の抑制と縮合などの副反応抑制とのバラ ンスの結果と思われる。溶媒効果の現象については多 くのことが知られているが，そのメカニズムはようや

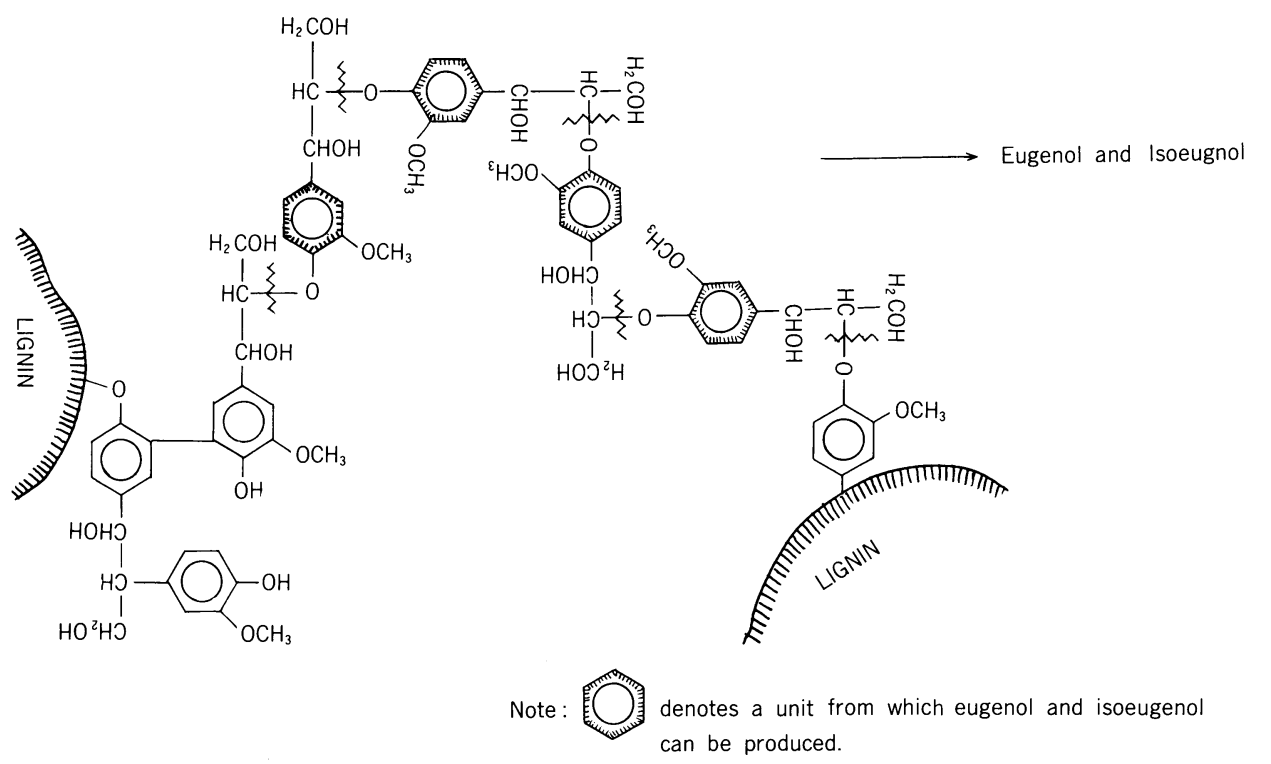

Fig.9 アルコール・バイサルファイト蒸解により低分子フェノールを生成すると思われるリグニ ン構造 


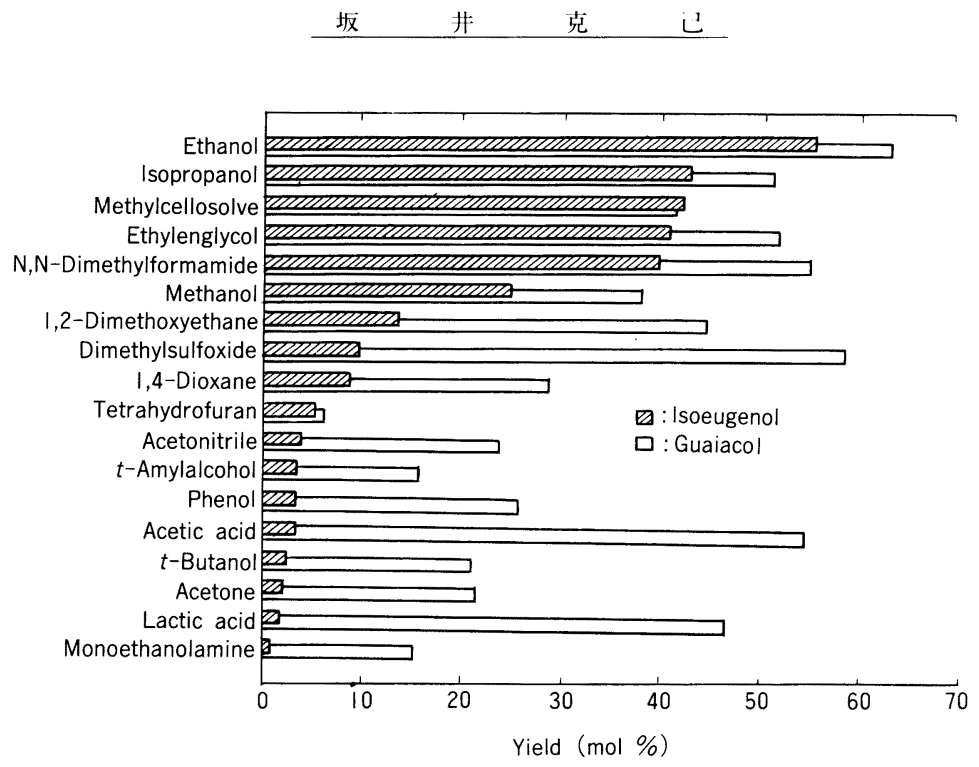

Fig.10 モデル化合物（12）からのイソオイゲノール収率に及ぼす溶媒の影響 $\left(\mathrm{NaHSO}_{3}\right.$ 濃度 : $1 \%$, 溶媒濃度 : $50 \%$, 処理温度 : $160^{\circ} \mathrm{C}$, 時間 : $\left.1 \mathrm{~h}\right)$

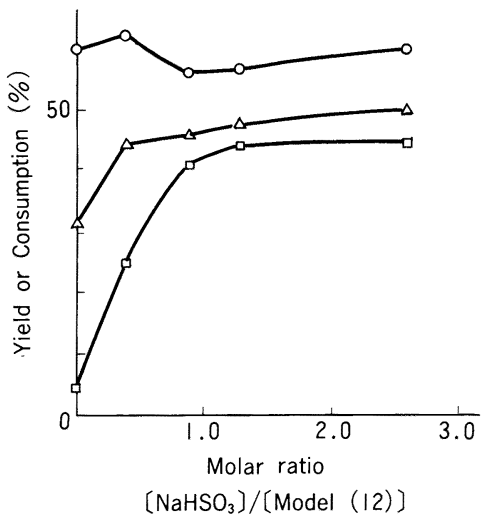

Alcohol-bisulfite system

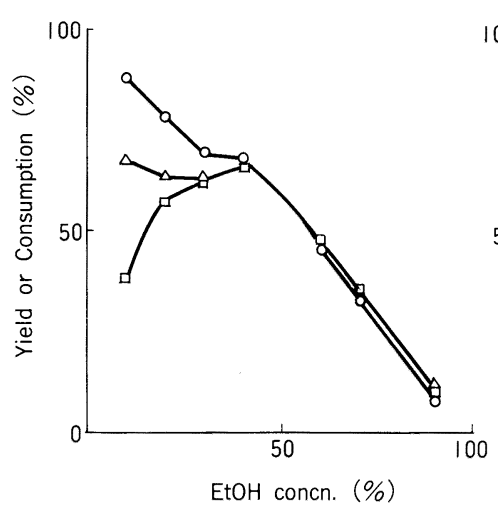

Bisulfite system

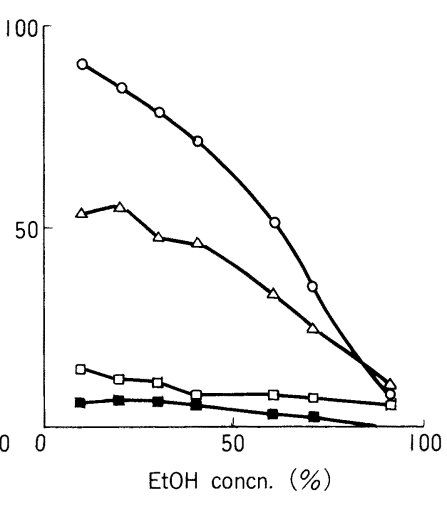

Non-bisulfite system

o Consumption of (12), $\backsim \Delta$ Guaiacol yield, $\square-\square$ Isoeugenol yield, $\longrightarrow$ Dehydrodi isoeugenol yield

Fig.11 モデル化合物（12）の反応に及ぼす $\mathrm{HSO}_{3}{ }^{-}$及び溶媒の濃度の影響（処理温度：160 ${ }^{\circ} \mathrm{C}$, 時間 $: 1 \mathrm{~h}$ ）

\section{く分かり始めたといえよう。}

なお, 出発物質をグアイアシルエーテルからシリン ギルエーテルに変えると開裂の程度は大きくなる（図 12）から，この場合にはキノンメチド中間体のの生成 が律速でないのであろう。この点についてはさらに検 討を続行中である。

\section{7. おわりに}

地球環境問題がクローズアップされるにつれ，オル ガノソルブパルプ化も環境に優しい面だけが強調され
る傾向にある。環境への適合性はもち万ん必要である にしても，経済的に利点がなけ机ば産業技術としては 成立しないことは当然である。ドイッやカナ多におけ る先駆的なオルガハソルブパルプ化の实用化への試み は，ここ数年の世界的な不洗を丵えると夕イムリーで はなかったかも知れないが, かえって経济性獲得に必 要な様々の技術的課題を示すことになるであろう。そ のような課題の克服に, 大学:の研兊がほんの一部でも 役立てばうれしいと考えている。 


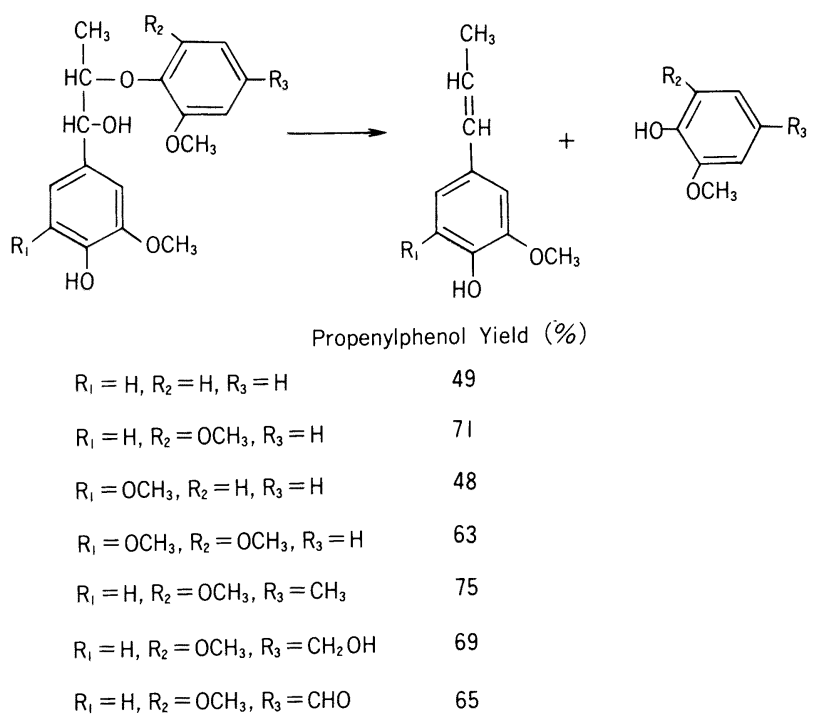

Fig.12 モデル化合物からのプロペニルフェノール収率

\section{参考文献}

1) T. N. Kleinert, K. Tayenthal : Angew. Chem., 44, 788-789 (1931). S. Aronovsky, R. I. Gortner : Ind. Eng. Chem., 26, 1270-1276 (1936)

2) 例えば, L. S. Nahum, P. Pellegrein : Svensk Papperstidn., 73, 725 (1970). J. Doucet, A. Robert: Holzforschung, 24, 164, 193 (1970). L. P. Clermont: Tappi, 53 (12), 2243 (1970).

3）佐野嘉拓：紙八技協誌，45，525-539（1991）。

4) W. Schweers, H. Behler, O. Beinhoff : Holzforschung, 26, 103-105 (1972). W. H. M. Schweers, Chemtech, p. 490-493 (Augst 1974).

5) J. Krieger : Chem. Eng. News, 38-39 (May 31, 1982). Pulp Paper Can., 85(7), 15-17 (1984).

6）榊原彰：紙パルプ技術タイムス，27(6)，21（1982）。 榊原彰，技重有鿆，武山浩武：紙パ技協誌，37, 423-429 (1983). 38, 337-344 (1984). A. Sakakibara, Y. Edashige, Y. Sano, H. Takeyama: Holzforschung, 38, 159-165 (1984).

7) Chem. Eng. News, p. 35-36 (Nov.3, 1980).

8) R. A. Young, J. L. Davis, E. B. Wiesmann: Proc. 1985 ISWPC, p. 169-172 (1985). Holzforschung, 40, 99-108 (1986). J. Haggin: Chem. Eng. News, p. 25-26 (Jan. 27, 1986).

8b) R. A. Young, T. Keith, J. Nelson, T.
Fredman : Proc. Conf. Solvent Pulping, p. 28 -34 (June 1987)

9) H. H. Nimz, R. Casten : Holz als Roh u. Werkstoff, 44, 207 (1986). H. H. Nimz, M. Schoene: Proc. 7 th ISWPC, vol. I, p. 258265 (1993).

10) Y. Sano, M. Nakamura, S. Shimamoto: Mokuzai Gakkaishi, 36(3), 207-211 (1990). 金 野晴男, 佐野嘉拓：第 38 回リグニン討論会講演 要旨集, p. 121-124（1993）.

11）松倉紀男，他 7 名：木材成分総合利用研究成果集 (同研究技術組合編)，1990, p. 53-64.

12）横山昭, 中嶋信之, 徳勝也 : 同上, p. 177-197.

13）中村雅幸，佐野嘉拓：第 35 回リグニン討論会要 旨集, p. 99-102 (1990).

14) T. N. Kleinert: Tappi 57(9), 99 (1974), 58(8) 170-171 (1975).

15) R. Katzen, R. E. Fredrickson, B. F. Brush : Pulp and Paper, p. 144-149 (August 1980). R. C. Myerly, M. D. Nicholson, R. Katzen, J. M. Taylor: Chemtech, p. 186-192 (March 1981).

16) J. H. Lora and S. Aziz: Tappi J., 68(8), 9497 (1985). J. H. Lora, 他 4 名：Proc. 1985 ISWPC, p. 181-182.

17) E. K. Pye, J. H. Lora : Tappi J., 74(3), 113118 (1991). P. N. Williamson: Pulp Paper 
Canada, 88(12), 47-49 (1987). J. H. Lora: Tappi J., 75(1), 12 (1992).

18) G. C. Goyal, J. H. Lora : Proc. 6th ISWPC, Vol. I, p.205-212 (1991). G. C. Goyal, J. H. Lora, E. K. Pye: Tappi J., 75(2), 110-116 (1992).

19）中野準三ら：紙八゚技協誌，30，650（1976），32, 245 (1978), 33, 418 (1979).

20）小林正明ら：紙分技協誌，32，525（1978）.

21) J. Feckl, E. Edel : Proc. 4th ISWPC, Vol. I, p. 369-372 (1987). G. Dahlmann, M. C. Schroeter: Tappi J., 73(8), 237-240 (1990). M. C. Schroeter: Tappi J., 74(10), 197-200 (1991).

22) Pulp Paper Intl., p. 74-77 (March 1990). J. Young : Pulp and Paper, p. 99-102 (September 1992). Paper Asia, p. 26-30 (May 1993).

23) R. Patt, O. Kordsachia : Papier, 40 (10 A), V 1 -V 8 (1986), 43(7), 293-301 (1989).

24) W. J. Bublitz, J. L. Hull : Intl. Sulfite Pulping Conf. (Tronto). p. 263 (1982). idem: Proc. 2nd IWSPC, Vol.III, 38 (1983).
25）文星筆，坂井克し，今井博之：第 27 回リグニン 討論会要旨集, p. 57-60(1982). 坂井克它, 文星筆, 今村博之：木材学会誌，29，291-292（1983）. K. Sakai, S. P. Mun, H. Imamura : Proc. 2nd ISWPC, Vol.IV, p. 194 (1983).

26）宇佐美国典, 高野勲, 玉办篤：第 33 四日本木材 学会要旨集, p. 244 (1983).

27）文星筆, 坂井克己, 今村博之：木材学会誌，34, 234-240, 241-245 (1988).

28) K. Sakai, S. P. Mun, H. Imamura : J. Wood Chem. Technol., 6, 523-524 (1986).

29) M. L. Minton, K. V. Sarkanen : J. Wood Chem, Technol., 4, 421-437 (1984).

30) K. Sakai, H. Takeuchi, S. P. Mun, H. Imamura: J. Wood Chem. Technol., 8, 29-41 (1988). K. Sakai, T. Takagi, H. Imamura : Mokuzai Gakkaishi, 36, 553-558 (1990).

31) P. Whiting, D. A. I. Goring: Paperi ja Puu, 64, 592 (1981)

32) E. Adler: Wood Sci. Technol., 11, 169 (1977).

33）黑田健一, 山日彰：38回リグニン討論会講演要 旨集, p. 5-8 (1993). 